Proc. Estonian Acad. Sci. Eng., 2004, 10, 1, 3-9

\title{
Strengthening of the surface layer microstructure with a laser beam
}

\author{
Regita Bendikienè, Sangaudas Chodočinskas, and Edmundas Pupelis
}

Department of Metal Technology, Kaunas University of Technology, Kestučio St. 27, 3004 Kaunas, Lithuania; \{regita.bendikiene, sangau, kat0709\}@ktu.lt

Received 1 September 2003, in revised form 3 November 2003

\begin{abstract}
Wear resistance and durability of the products depend on the nature of the solid solution and microstructure. Minimal wear have materials with optimum alloyed solid solution and fine particles, usually carbide inclusions. Such a structure is difficult to obtain using traditional methods of manufacturing. Blanks of alloyed steels have coarse grains and carbide inclusions of undesirable shape, arranged discretely. To change such a microstructure is impossible. Therefore the purpose of the present paper is to create a desirable microstructure using micrographical laser beam treatment and to evaluate the influence of treatment parameters and point drawing to wear resistance of the surface layer.
\end{abstract}

Key words: wear resistance, surface strengthening, laser treatment.

\section{INTRODUCTION}

Laser beam treatment of superficial layers is a progressive strengthening method. For heat treatment lasers of $1-5 \mathrm{~kW}$ are suitable. Laser treatment, comparing with other methods of surface treatment, has many advantages. It gives the possibility to obtain a superficial layer of desired properties, to add alloying elements, to localize the strengthening effect, to carry out finishing operations, to obtain a surface with desired roughness, and to increase corrosion resistance of superficial layers. Besides, this process can be automated. The main disadvantages of the laser treatment are high price of the laser equipment and the need for highqualified personnel.

High density of power in the impulse and continuous regimes, high coherence and monochromatic level are the main properties of the laser radiation. Treatment of various materials is based on the interaction of the laser beam with the material. 
Due to the absorption of the laser beam during this interaction, the material surface becomes heated, the material melts and sometimes evaporates $\left.{ }^{1}\right]$.

After laser beam treatment, different structures can be observed: blocks and fine-grained phases, grains and coarse-grained phases, and solid inclusions. High velocity quenching results in the formation of solid inclusions. Performed metallographical investigations in the heat-treated zone show structural changes, related to changes of the grain shape and size and also to the formation of solid inclusions during rapid quenching $\left[{ }^{2}\right]$. Structural changes in the structural and tool steel, obtained after laser beam treatment, are similar to those obtained using other methods of rapid heating. However, due to specific characteristics of laser radiation, the same characteristic features appear in the treated steel. One such feature is abnormally high surface hardness $\left[{ }^{3,4}\right]$.

Defects of the crystalline structure (dislocations, vacancies, etc.) noticeably influence the strengthening. During rapid quenching, austenite and carbide particles fuse and obtain a structure that consists of martensite and particles of non-fused cementite that influence hardness of the treated material $\left[{ }^{2}\right]$.

Metallographical investigations reveal in the structure of hardened steel of grade 45 three zones according to the Russian standard $\left[^{5}\right]$ : $(0.42-0.50 \% \mathrm{C} ; 0.17-$ $0.37 \% \mathrm{Si} ; 0.50-0.80 \% \mathrm{Mn}$ ). They correspond to fine-grained, sorbite-troostite, and coarse-grained martensite, respectively. Structure of the normalized steel 45 after laser beam treatment shows essential changes in the circular zone. Zone of fused pearlite of $75 \mu \mathrm{m}$ thickness, separated from the parent metal by slag inclusions, can be observed on the top. Results of X-ray structural analysis show that this layer is highly decarburized. Zones of martensite are observed in the region near the crater $(10 \mu \mathrm{m}$ and more); in the deeper layers of the material $(300-450 \mu \mathrm{m})$ a layer of incomplete hardening appears. Analogical changes of the structure show steels of grades Y8 $(0.75-0.84 \% \mathrm{C} ; \quad 0.17-0.33 \% \mathrm{Si} ; \quad 0.17-0.33 \% \mathrm{Mn} ; \geq 0.028 \% \mathrm{~S}$; $\geq 0.030 \%$ P), WX15 (0.95-1.05\% C; $0.20-0.40 \% \mathrm{Mn} ; 0.17-0.37 \% \mathrm{Si} ; 1.35-$ $1.65 \% \mathrm{Cr} ; 0.30 \% \mathrm{Ni})$, and ХВГ $(0.90-1.05 \% \mathrm{C} ; 0.10-0.40 \% \mathrm{Si} ; 0.80-1.10 \% \mathrm{Mn}$; $0.90-1.20 \%$ Cr; $1.20-1.60 \%$ W) $\left[{ }^{6,7}\right]$.

\section{TEST PROCEDURES}

Micro-spectral analyser MLA 10 with ruby laser radiation was used for the micrographical thermal point strengthening. Laser beam modification is possible altering the filter, diaphragms, and the objective lens and changing parameters of the power supply unit.

The laser beam analyser evaporates various metal ingredients; outcome of this process is formation of recesses of a definite size with a white zone in the periphery. It is possible to vary the geometrical parameters of the strengthened zone: depths from 1 to $700 \mu \mathrm{m}$ and diameters from 10 to $2000 \mu \mathrm{m}$.

Influence of the parameters of the laser beam analyser on the geometry of strengthened zones was analysed on test pieces of structural and tool steel. 
Surface with evaporated recesses was formed after micrographical strengthening. Due to high radiation concentration and high heat absorption in the test piece, white zones in the periphery of the recesses appeared. Thickness of the white zone and diameter and depth of the recesses depend on the cassette of the modulator, on the diaphragms, and on the objective lens of the microscope.

\subsection{Heat treatment}

Test pieces were subjected to heat treatment in laboratory furnaces. Parameters of heat treatment were chosen according to the geometrical parameters of the test piece. The test pieces were prepared from structural steel 45 , and tool steels X12Ф1 (1.25-1.45\% C; 0.15-0.35\% Si; 0.15-0.40\% Mn; $11.00-12.50 \%$ Cr; 0.70 $0.90 \% \mathrm{~V}$ ) and $\mathrm{Y} 8$. The composition conforms to the requirements of the Russian standard GOST.

Rockwell hardness of the two test pieces prepared from the structural steel 45 after heat treatment (heating up to $850^{\circ} \mathrm{C}$, cooling in water, and tempering at 550 and $250^{\circ} \mathrm{C}$ ) was 44 and $56 \mathrm{HRC}$. Hardness of the tool steel $\mathrm{Y} 8$ specimens was 40 and $54 \mathrm{HRC}$ after the following heat treatment: heating up to $800^{\circ} \mathrm{C}$, cooling in water, and tempering at 400 and $250^{\circ} \mathrm{C}$. The test pieces prepared from the die steel showed hardness of 44 and $56 \mathrm{HRC}$ after the following heat treatment: heating up to $1050^{\circ} \mathrm{C}$, cooling in oil, tempering at 550 and $250^{\circ} \mathrm{C}$.

\subsection{Test procedures for evaluation of wear resistance}

Durability of the tools and products is based on the wear resistance of the components. Investigation of wear resistance of the test pieces followed laser beam strengthening and heat treatment. In order to estimate the influence of micrographical strengthening on the durability of the superficial layer, a technique that allows to examine wear processes in small areas was used. Cylindrical test piece is shown in Fig. 1.

Wearing surface was maximally reduced to a narrow strip, into which the indenting tool of the Rockwell hardness test machine leaves an indentation. Due to the small area of the wearing surface, it was possible to evaluate the influence of micrographical strengthening on the wear resistance of steels. Suggested

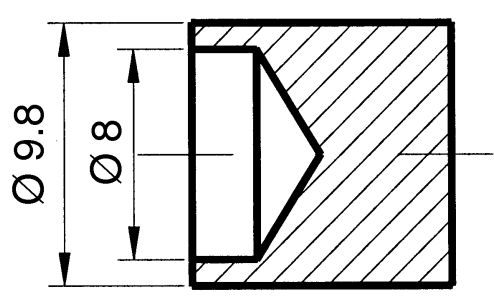

Fig. 1. Test piece. 
method of pressing allows free movement of the test piece in the holder, but edges of the test piece remain sharp. Thus during wearing, surface of the test piece was flat. This enabled to evaluate not only the indentation but also the alteration of structural elements of the steel during wearing.

Digital metallographical evaluation of wear was used. After some cycles of wearing, the digital camera $\mathrm{YCCH}-15$ records a view of the conical imprint, and computer software determines the area of the imprint. Knowing the angle of conical indentor $\left(120^{\circ}\right)$ it is possible to calculate the height of the worn surface layer. This measurement was performed with an accuracy of $1 \mu \mathrm{m}$. Following equations were used for the calculation of the height $h$ of the worn surface layer:

$$
r=\sqrt{\frac{S}{\pi}}, \quad h=\tan 60^{\circ} \sqrt{\frac{S}{\pi}}, \quad \Delta h=\tan 60^{\circ}\left(\sqrt{\frac{S_{1}}{\pi}}-\sqrt{\frac{S_{2}}{\pi}}\right),
$$

where $r$ and $S$ are the radius and the cross-sectional area of the imprint and $S_{1}$ and $S_{2}$ are the initial and worn cross-sectional area of the imprint, respectively.

\section{EXPERIMENTAL}

Remarkable effect on the durability of tools and other products have properties of the superficial layers. Wear resistance and durability of the product depend on alloying elements of the solid solution and microstructure. Highest wear resistance have materials with optimal alloyed solid solution and fine equally arranged hard particles and carbide inclusions. It is difficult to obtain such a structure using traditional methods of billet manufacturing. The structure of alloyed steel consists of coarse unevenly arranged particles of undesirable shape. To alter this structure is very difficult and sometimes even impossible. We succeeded in creating a desirable microstructure in the superficial layers of the product using micrographical method of laser beam treatment. Such a point strengthening does not cause strains in the superficial layers and also strains between the layer and the parent metal, because conditionally soft matrix of the product reduces strains between the thermally strengthened zone and the matrix.

The hardness test is the most common method of estimation of mechanical properties of the material. For that a test load of $1 \mathrm{~N}$ was used with testing step $0.01 \mathrm{~mm}$ through the strengthened zone. Thus the whole surface around the recess was tested.

Results of the hardness test of the tool steel $\mathrm{y} 8$ and structural steel 45 show that maximum hardness have the slopes of the recesses. Hardness reduces with approaching the virgin portion of the material and in some cases a self-tempered zone can be observed. Such a behaviour was observed in the strengthened zones of the test pieces prepared from the steel 45 when the hardness of the parent metal was greater than $40 \mathrm{HRC}$. Test pieces prepared from the steel Y8 showed this behaviour when hardness was greater than $30 \mathrm{HRC}$. Cohesion between the 
matrix and the strengthened zone in the test pieces of the eutectoid steel is relatively low. It is possible that in exploitation tempered zones can be deformed by zones of highest hardness. Strengthened zones of steels did not reveal selftempered zones when hardness of the parent metal was lower.

Test results showed that hardness of the strengthened zones of the carbon tool steel does not depend on the hardness of the parent metal. Hardness of strengthened zones of $\mathrm{Y} 8$ is the same. Low hardness difference can be observed in the test pieces of steel 45. When hardness of the parent metal exceeds $50 \mathrm{HRC}$, the hardness of the strengthened zone is higher for $11 \%$. Another character of strengthened zone hardness was observed when testing die steels X12Ф1. Studying results of the hardness test we discovered that the slopes of the white zone around the recesses have different hardness. Temperature in the slopes is uneven when the layer is formed. The top layers of the slopes warm up better than the deeper layers. After strengthening, a high quantity of austenite was formed and hardness of the white zone decreased. Such effect of hardness reduction was observed also in the test pieces with parent metal hardness of 44 HRC.

Formation of the retained austenite in the slopes is a positive phenomenon because during working, when relative pressure is high, the material transforms into martensite which increases wear resistance. Test showed that hardness of the strengthened zones of steel X12Ф1 depends on the hardness of the parent metal.

Most details and tools work in hard intensive wearing conditions. Therefore the durability depends on the wear resistance of the superficial layers. Very localized zones of the product can be strengthened, creating a graphical scheme of strengthened zones.

A technology of the laser beam treatment and two schemes of strengthening were designed. Wear resistance of the test pieces prepared from the structural and tool steels, strengthened with the suggested procedure, was tested. Test results are given in Table 1 .

According to the test results, we can state that wear resistance of not strengthened steel Y8 depends on the hardness. Higher wear resistance have test pieces with a hardness of 54 HRC. Curve of wear resistance of not treated test pieces is close to the straight line.

Wear resistance of the test pieces increased after laser strengthening. Wear curve character varied, because of the reduction of the strengthened zone area during working. Higher wear resistance was obtained using the second scheme of treatment. A density of strengthening zones using the first scheme was 2.6 points $/ \mathrm{mm}^{2}$ and for the second one 5.2 points $/ \mathrm{mm}^{2}$. Such a tendency is independent of the hardness of the parent metal.

When hardness of the parent metal Y8 reduces, wear resistance increases. Such a phenomenon is important for the products when high plasticity is needed. Formation of the self-tempered zones reduces wear resistance of the test pieces with higher parent metal hardness. The self-tempered zones separate the strengthened zones and the matrix. Wear resistance of the carbon tool steel can be increased for four times using the second scheme of strengthening. 
Table 1. Wear of the test pieces

\begin{tabular}{|c|c|c|c|c|c|c|c|c|}
\hline \multirow{3}{*}{$\begin{array}{c}\text { Steel } \\
\text { and } \\
\text { hardness }\end{array}$} & \multirow{3}{*}{$\begin{array}{l}\text { Strengthening } \\
\text { scheme }\end{array}$} & \multicolumn{7}{|c|}{ Height of wearing, $\mu \mathrm{m}$} \\
\hline & & \multicolumn{7}{|c|}{ Sliding distance, $\mathrm{m}$} \\
\hline & & 150 & 300 & 450 & 600 & 750 & 900 & 1050 \\
\hline \multirow{3}{*}{$\begin{array}{c}\text { Y8 } \\
54 \text { HRC }\end{array}$} & - & 3.20 & 6.10 & 9.00 & 12.10 & 15.40 & 18.80 & 22.31 \\
\hline & 1 scheme & 2.00 & 3.70 & 5.80 & 8.10 & 10.80 & 14.20 & 18.60 \\
\hline & 2 scheme & 1.10 & 2.30 & 3.80 & 5.60 & 7.70 & 10.80 & 14.60 \\
\hline \multirow{3}{*}{$\begin{array}{c}\text { Y8 } \\
40 \text { HRC }\end{array}$} & - & 4.40 & 8.70 & 12.60 & 16.70 & 20.70 & 24.80 & 29.25 \\
\hline & 1 scheme & 1.30 & 2.50 & 3.30 & 4.50 & 6.30 & 8.60 & 11.70 \\
\hline & 2 scheme & 0.70 & 1.20 & 1.70 & 2.50 & 3.40 & 4.80 & 7.10 \\
\hline \multirow{3}{*}{$\begin{array}{c}45 \\
50 \mathrm{HRC}\end{array}$} & - & 3.60 & 7.40 & 11.00 & 15.20 & 18.90 & 22.90 & 27.36 \\
\hline & 1 scheme & 1.90 & 3.00 & 4.80 & 7.20 & 10.30 & 14.50 & 19.46 \\
\hline & 2 scheme & 0.80 & 1.70 & 2.80 & 4.40 & 6.40 & 9.20 & 12.73 \\
\hline \multirow{3}{*}{$\begin{array}{c}45 \\
30 \mathrm{HRC}\end{array}$} & - & 4.20 & 8.30 & 12.80 & 18.20 & 23.50 & 29.30 & 35.40 \\
\hline & 1 scheme & 2.40 & 4.80 & 7.90 & 12.00 & 18.00 & 24.20 & 31.80 \\
\hline & 2 scheme & 1.40 & 3.10 & 5.50 & 9.50 & 14.90 & 21.00 & 28.12 \\
\hline \multirow{3}{*}{$\begin{array}{l}\text { X12Ф1 } \\
56 \text { HRC }\end{array}$} & - & 2.00 & 3.38 & 5.26 & 7.05 & 8.93 & 10.80 & 12.97 \\
\hline & 1 scheme & 1.28 & 2.16 & 3.20 & 4.32 & 5.60 & 7.60 & 10.27 \\
\hline & 2 scheme & 0.89 & 1.50 & 2.10 & 3.00 & 4.30 & 6.10 & 8.86 \\
\hline \multirow{3}{*}{$\begin{array}{l}\text { X12Ф1 } \\
44 \text { HRC }\end{array}$} & - & 1.95 & 3.83 & 5.77 & 7.72 & 9.81 & 12.10 & 14.33 \\
\hline & 1 scheme & 0.89 & 1.39 & 1.89 & 2.40 & 3.38 & 4.57 & 6.87 \\
\hline & 2 scheme & 0.40 & 0.70 & 0.95 & 1.30 & 1.90 & 3.00 & 4.69 \\
\hline
\end{tabular}

Wear resistance of structural steel 45 (hardness of the parent metal 50 HRC) increases despite of the formation of the self-tempered zones. First scheme of the strengthening increases wear resistance of the test piece for $26 \%$, and the second one for $52 \%$. These effects decrease and wear resistance increases negligibly when the hardness of the parent metal is reduced to 30 HRC. It can be explained by the equalization of the parent metal hardness and hardness of the selftempered zone.

Wear resistance of the test pieces prepared from the steel X12Ф1 without strengthening effect depends on the hardness. The main influence on the wear resistance of this steel has the carbide phase. The slopes of recesses formed during micrographical strengthening warm up unevenly, internal layers warm up better. After such a heating and cooling, retained austenite is formed and high hardness of the white zone remains just in the narrow rim. Retained austenite transforms into martensite during working. Due to these changes, wear resistance of the test pieces increases. Maximum effect of strengthening, using test pieces of the steel X12Ф1, was obtained when hardness of the parent metal was 44 HRC. Using the second scheme of the strengthening, wear resistance increases for three times. Formation of retained austenite increases hardness further. 


\section{CONCLUSIONS}

1. Self-tempered zones are formed around the strengthening recesses of test pieces prepared from the carbon tool steel.

2. Micrographical strengthening of the surface increases wear resistance of eutectoid steel for 4 times, of structural steel for 2 times, and of die steel for 3 times.

3. The described technology of strengthening can be used for increasing the durability of final products and tools.

\section{REFERENCES}

1. Trofimov, V. T. Influence of intensive ultrasound and laser beam on the structure and mechanical properties of steel. Thesis. Gorkyi, 1981 (in Russian).

2. Rykalin, N. N., Uglov, A. A., and Kokora, A. N. Influence of OGK radiation on the iron alloys. Fizicheskaya i Himicheskaya Obrabotka Materialov, 1972, No. 6, 14-20 (in Russian).

3. Kokora, A. N. et al. Treatment of steel by laser beam. Metallovedenie i Termicheskaya Obrabotka, 1980, No. 2, 41-42 (in Russian).

4. Berchovskyi, V. F., Zhukov, A. A., Kokora, A. N., and Uglov, A. A. About local surface hardening by radiation OGK. Fizicheskaya i Himicheskaya Obrabotka Materialov, 1969, No. 4, 35-44 (in Russian).

5. Belanin, V. A., Zhukov, A. A., Kokora, A. N., and Tusheva, A.A. Structure and hardness of superficial layers after laser beam treatment. Fizicheskaya i Himicheskaya Obrabotka Materialov, 1967, No. 2, 115-116 (in Russian).

6. Glikan, L. A., Krylov, K. I., and Rubashkina, Z. M. Influence of laser beam on the steel. Problemy Kvantovoi Elektroniki, 1967, 61, 58-68 (in Russian).

7. Anenkov, V. D., Barchukov, A. I., and Davydov, J. T. Investigation of steel and cast iron structure in the zone of laser treatment. Fizicheskaya $i$ Himicheskaya Obrabotka Materialov, 1974, No. 2, 38-42 (in Russian).

\section{Pinnakihi mikrostruktuuri tugevdamine laserkiirega}

\section{Regita Bendikienè, Sangaudas Chodočinskas ja Edmundas Pupelis}

Materjalide ja toodete kulumiskindlus ja tööiga sõltuvad mikrostruktuurist minimaalse kulumisega on peente, tavaliselt karbiidsete lisanditega optimaalselt legeeritud tardlahuse struktuuriga sulamid. Selliseid struktuure on raske saada traditsiooniliste meetoditega, sest legeerterastest toorikud on jämeteralised ja karbiidsed lisandid reeglina ebasoovitava kujuga, mida on raske muuta. Käesolevas töös on esitatud meetod soovitava mikrostruktuuri saamiseks, kasutades selleks pinnakihi mikrostruktuuri töötlemist laserkiirega. Samuti on hinnatud töötlusparameetrite ning -skeemi mõju pinnakihi kulumiskindlusele. 